\title{
Role of Cottage Industry in the Economic Development of Bangladesh: An Empirical Study
}

\author{
Sadia Tasneem ${ }^{1}$, Md. Rouf Biswas ${ }^{2}$ \\ ${ }^{1}$ Lecturer in Economics, Department of Business Administration, Northern University Bangladesh. \\ ${ }^{2}$ Assistant Professor of Accounting, Department of Business Administration, Northern University Bangladesh.
}

\begin{abstract}
Economic development generally refers to the quantitative and qualitative changes in the economy to promote the standard of living and economic health of a specific area. This article focuses on the role of cottage industry in economic development. We have identified various factors of economic development on which the cottage industry is contributing a lot. To explain it we have collected primary data through structured questionnaire. This paper also discusses the problems associated with cottage industry. Five sectors of cottage industry have been included into this study. This paper focuses on the contribution of each sector to the economic development of Bangladesh. Finally, some recommendations are put forth for the development of cottage industry so that this industry can thrive and contribute more to the economic development of Bangladesh.
\end{abstract}

Key Words: Cottage Industry, Economic Development, Bangladesh.

\section{Introduction}

Cottage Industry refers to the traditional artisanship of the rural people of Bangladesh, who produce various household items with locally available raw materials and artistic skills inherited from past generations. For their own use and for livelihood, they make those artistic products by hand depicting the designs and motif of the nature of Bangladesh and its people, birds and animals, foliages, plants and trees, rivers, streams and sky. Cottage industry is called a synonym of handicrafts, artistic work in wood and metal, amateur artworks and rural artistry. At present the cottage industry has expanded to the urban area. ${ }^{1}$

Cottage industries provide economic opportunities for the poor or the middle-income section of people through employment and income generation schemes all over the world, and especially in low income and technologically underdeveloped countries such as Bangladesh. ${ }^{2}$

Traditionally, cottage industries have been rural-based, but in course of time and with technological advancements, they spread to urban areas to avail of transport and marketing facilities and financial support from institutional sources. The area of cottage industries has now broadened remarkably from simple indigenous technology based and home-made products to sophisticated handicrafts of wide varieties. Among the cottage industries of Bengal, cotton is the most important, and has a history of at least two thousand years. During Roman times, muslin of Eastern Bengal was a passion and a fashion for the richest Roman ladies. One of the striking characteristics of Bengal's handloom cotton textile and silk industry was their exceptional diffusion throughout the country. In pre-British Bengal, the cotton industry was organized under pure handicraft or the domestic system of production. Small but independent producers carried on the process of production with the assistance of their own families and occasionally with the help of waged laborers. Some craftsmen, artisans, and other small industrial entrepreneurs and workers were dependent on the capital of money-lenders. During the Mughal era, cottage industries were allowed to flourish. Only a few weavers who worked in the royal factories were affected to some extent because of Mughal rules. With the coming of Europeans, the domestic system of production of cottage industries became much more common. Then European merchants, including the English and Dutch East India Companies, financed artisans, weavers, and other handicraft workers for producing goods for export to foreign destinations. Company officials, however, attempted to oppress handloom cotton textile, weaving, and other cottage industries. British rulers imposed series of repressionary regulations by which they controlled price and production of textile and other cottage industry goods. In addition, the regulatory constraints, physical torture, forfeiting of goods, seizure of property, and prosecution for recovery of advances stifled weavers and made them disinclined to work for the East India Company. In fact, many indigenous artisans gave up their professions in protest. ${ }^{3}$

This study focuses on the role of cottage industry in economic development. Cottage industries are labour intensive and have the ability to utilize the excess labour. It needs low technology. In this sector private savings is important for investment and capital accumulation as there is less access to formal credit system. Cottage industries can help a lot in this respect by providing forward and backward linkages with agriculture, manufacturing, and the mainstay of the economy. It uses local raw materials and energy supplies i.e. it tries to 
ensure domestic resource mobilization. It satisfies local market demand, encourages local initiative and entrepreneurship.

Bangladesh Small and Cottage Industries Corporation (BSCIS) is responsible for promotion and registration of small and cottage industries; conducting advisory and industrial promotion services including scouting and training of entrepreneurs, skill development of artisans and craftsman and creation of job opportunities; construction and development of industrial estate with necessary infrastructure facilities for the Small and Cottage Industries (SCIs); and for development of linkages between SCIs and other medium and large industries. Involvement of women entrepreneurs in Small and Cottage industries is increasing day by day, which is a good news. The Women Entrepreneurship Development Programme (WEDP), initiated by the BSCIC with United States Agency for International Development (USAID) assistance, is concerned with poverty alleviation among rural disadvantaged women.

\section{Review Of Related Literature}

Khursida \& Begum (1992), from a survey of women involved in business and women interested in business (potential entrepreneurs), identified 31 trades and businesses that are attractive to female entrepreneurs: plant nurseries, the stock market, boutiques, beauty parlours, advertising and films, tailoring, flower plantations, handicrafts, costume design, food processing, printing, day farming, flower clubs, shop-keeping, import, plastics, sewing and cooking training centres, knitting, video centres, and dish antenna assembly.

A study (Khandoker 1998) regarding financing to small-scale and cottage Industries in Bangladesh reveals that in many cases credit is obtained from suppliers in the form of raw materials or from the buyers of the firm's output. The study demonstrated that about 70 per cent of the start-up cost in respect of small grocery stores was financed from the owner's savings and sales of other assets. Friends and relatives provided loans to the extent of 20 per cent on average, and the supplier's credit financed about 10 per cent of the start-up cost.

Marx (1987) suggests that the destruction of natural rural economy and consequently its economy began with the agricultural revolution -in the last quarter of the 15th century and most of the 16th century and is completed when the capitalist mode of production is introduced. The destruction of rural industry resulted in the separation of city and rural areas - manufacturing processes were developed in cities, and only activities pertaining to cultivation and livestock production remained in the rural areas. Thus, the separation between agriculture and manufacturing occurs. This separation, therefore, begins with the manufacturing process and is completed with capital production. It is thus possible to say that when capitalism is introduced in agriculture, it leads to the destruction of rural industry.

Graziano da Silva (1998) suggests that families that live in rural areas and are involved in activities that coexist with traditional farming have, on the average, an income that is 43 percent higher than farmers, who are exclusively involved in traditional agriculture.

Bangladesh Agricultural University Extension Centre (BAUEC) have to motivate, educate and help farmers to make all-round development by their local and own resources through six development components such as crop development, livestock development, fish development, adult education, health and family planning and cottage industries. (BAUEC, 2001).

Although promotion of Small and Medium Enterprise (SME) development has been a stated objective of successive governments ever since Pakistan days, the broad macro policy regime has continued to remain biased against SME development in many ways. Allocation of public sector investments, trade policies and taxation policies in particular has mostly been anti-SME development in character and contents (ADB, 2002).

\section{Objectives Of The Study}

The main objective of this paper is to identify the role of cottage industry in the economic development of Bangladesh. The supportive objectives are following:

(i) To identify which industry plays more vital role for economic development

(ii) To find out problems of the cottage industries.

(iii) To formulate and test hypothesis of the role of cottage industry in the economic development

(iv) To make some policy recommendations for overcome those problems.

\section{Methodology Of The Study}

4.1 Sources of the Data: This study is mainly based on primary data source. Interview technique was used with structured questionnaire for the collection of primary data. In a questionnaire, besides close-ended questions there was also provision for open-ended optional questions. Sources of raw materials, income- expenditure pattern are mainly included in the questionnaire. Primary data is collected from field survey. The obtained information are edited and summarized in sequential order. 
4.2 Sample Size: For preparing this article, at first we acquire some knowledge about the five types of cottage industry in Khulna region such as Boutique shop, Nursery, Pottery, Cane and Food. Since it was impossible to take into account all the relevant and related aspects of cottage industry of the study area, representative subsets from the whole cottage industry were taken as samples. We have also collected data from 50 people who are the outsiders for presenting their opinion on the role of cottage industry in economic development in Bangladesh.

TABLE 1

Overview of sample size

\begin{tabular}{|c|c|c|c|}
\hline Data Collection Period & Collected By & Industry Type & Number of Respondents (owner) \\
\hline October -December, 2013 & Researchers & Boutique Shop & 6 \\
\cline { 3 - 4 } & & Nursery & 3 \\
\cline { 3 - 4 } & & Pottery & 5 \\
\cline { 3 - 4 } & & Cane & 4 \\
\cline { 3 - 4 } & & Food. & 2 \\
\hline
\end{tabular}

4.3 Analysis of the Data: Collected data and information have been organized, explained and analyzed by using different statistical tools and techniques. This study is completed in an analytical and descriptive way.

\section{Theoritical And Conceptual Framework \\ Cottage Industries}

When family members carry a small -scale industry by using their own equipments, it is called cottage industry. In this type of industry labor force consists of family units or individuals working from home with their own equipments.

\section{SECTORS, SUB-SECTORS, AND MAJOR TYPES OF COTTAGE INDUSTRY}

TABLE 2

Eight broad cottage industry sectors, a number of sub-sectors, and major types under each sector.

\begin{tabular}{|l|l|c|l|}
\hline Sector & $\begin{array}{l}\text { No. of sub- } \\
\text { sectors/types }\end{array}$ & Major types \\
\hline 1. & Food \& allied industries & 40 & $\begin{array}{l}\text { Rice husking, oil mills, gur making, } \\
\text { pulse milling, chira making, sweet } \\
\text { meat }\end{array}$ \\
\hline 2. & $\begin{array}{l}\text { Textile, wearing apparel \& } \\
\text { leather industries }\end{array}$ & 41 & $\begin{array}{l}\text { Tailoring, mats \& reeds, fish net, } \\
\text { jute handicrafts }\end{array}$ \\
\hline 3. & $\begin{array}{l}\text { Wood \& wood products } \\
\text { (including bamboo \& cane } \\
\text { products) }\end{array}$ & 14 & $\begin{array}{l}\text { Wood products, bamboo \& cane } \\
\text { products, wood handicraft \& } \\
\text { furniture }\end{array}$ \\
\hline 4. & $\begin{array}{l}\text { Paper, paper products, } \\
\text { printing \& publishing }\end{array}$ & 12 & $\begin{array}{l}\text { Printing presses, book binding, } \\
\text { paper bags, etc. }\end{array}$ \\
\hline 5. & $\begin{array}{l}\text { Chemicals, petroleum, coal, } \\
\text { rubber \& plastic products }\end{array}$ & 35 & $\begin{array}{l}\text { Plastic footwear, soap-making, } \\
\text { agarbati, vulcanizing }\end{array}$ \\
\hline 6. & Glass \& ceramics & 12 & Pottery, tiles \\
\hline 7. & $\begin{array}{l}\text { Fabricated metal products, } \\
\text { machinery \& equipment }\end{array}$ & 32 & $\begin{array}{l}\text { Line and cement products, hand } \\
\text { tools, light engineering workshops, } \\
\text { agricultural implements, electrical } \\
\text { appliances. }\end{array}$ \\
\hline 8. & $\begin{array}{l}\text { Other manufacturing } \\
\text { industries \& handicrafts }\end{array}$ & 25 & $\begin{array}{l}\text { Gold smithies, handicrafts, hand } \\
\text { fans, etc. }\end{array}$ \\
\hline Source: Survey on cottage industries, BSCIC, 1994. \\
\hline
\end{tabular}

\section{Boutique shop}

A small shop or a small specialty department within a larger store, especially one that sells fashionable clothes and accessories or a special selection of other merchandise. ${ }^{4}$

Recently, the term "boutique" has started being applied to normally-mass-market items that are either niche or produced in intentionally small numbers at very high prices. This may be referred to as boutique manufacturing. For example, before the release of the Wii, a Time Magazine article suggested that Nintendo could become a "boutique video-game company", producing games for niche audiences, rather than trying to compete directly with Microsoft and Sony. ${ }^{5}$ 


\section{Nursery}

A nursery is a place where plants are propagated and grown to usable size. They include retail nurseries which sell to the general public, wholesale nurseries which sell only to businesses such as other nurseries and to commercial gardeners, and private nurseries which supply the needs of institutions or private estates. Some retail and wholesale nurseries sell by mail. ${ }^{6}$

\section{Pottery}

Pottery is the ceramic act of making pottery wares, of which major types include earthenware, stoneware and porcelain. The place where such wares are made is also called a pottery (plural "potteries"). Pottery also refers to the art or craft of a potter or the manufacture of pottery.

Pottery is made by forming a clay body into objects of a required shape and heating them to high temperatures in a kiln which removes all the water from the clay, which induces reactions that lead to permanent changes including increasing their strength and hardening and setting their shape. A clay body can be decorated before or after firing. Prior to some shaping processes, clay must be prepared. Kneading helps to ensure an even moisture content throughout the body. Air trapped within the clay body needs to be removed. This is called de-airing and can be accomplished by a machine called a vacuum pug or manually by wedging. Wedging can also help produce an even moisture content. Once a clay body has been kneaded and de-aired or wedged, it is shaped by a variety of techniques. After shaping it is dried and then fired. ${ }^{8}$

\section{Cane}

Cane is either of two genera of tall, perennial grasses with flexible, woody stalks from the family Poaceae that grow throughout the world. The genera include species of bamboo. Depending on strength, cane can be fashioned for various purposes such as tools and walking sticks/crutches. Judicial canes, or school canes. Where canes are used in corporal punishment, they must meet particular specifications, such as a high degree of flexibility. Cane historically has been used for many other purposes such as baskets, furniture, boats, roofs and wherever stiff, withy sticks can be put to good use. ${ }^{9}$

\section{Food}

Any nourishing substance that is eaten, drunk, or otherwise taken into the body to sustain life, provide energy, promote growth, etc. ${ }^{10}$

The current industrialisation strategy is yet to come terms with addressing the emerging challenges and structural bottlenecks adequately, both in domestic and global levels. In FY 2011-12, the share of agricultural, industrial and service sector in GDP was 19.29 percent, 31.26 percent and 49.45 percent respectively which was 73 percentage points lower, 89 percent higher and 1.5 percentage points less than that of FY 2010-11. Over the years, the economy of Bangladesh has undergone significant structural transformation in terms of sectoral contribution to GDP.

TABLE 3

Salient features of SCI in Bangladesh

\begin{tabular}{|l|c|c|c|c|c|c|}
\hline \multicolumn{1}{|c|}{ Factors } & Fy06-07 & Fy07-08 & Fy08-09 & Fy09-10 & Fy10-11 & Fy11-12 \\
\hline $\begin{array}{l}\text { Contribution of Small and Cottage Industry } \\
\text { Sector to GDP (in \%) }\end{array}$ & 5.08 & 5.14 & 5.18 & 5.26 & 5.29 & 5.26 \\
\hline $\begin{array}{l}\text { Growth of Small and Cottage Industry Sector } \\
\text { to (in \%) }\end{array}$ & 9.69 & 7.10 & 6.90 & 7.77 & 5.84 & 7.18 \\
\hline
\end{tabular}

Source: Ministry of Finance, Government of Bangladesh (GOB), Bangladesh Economic Review -2012

\section{Analysis And Discussion}

Cottage industries are playing a vital role in the economic development in Bangladesh. To focus the role of these industries in the economic development we have analyzed our collected data into the various categories which are as follows:

(i) Improvements of literacy rates: Improvement of literacy rate is one of the important measures of economic development. Cottage industries are contributing more to improve literacy rate. To focus this we have shown our collected date during the last five as follows with the establishment cottage industries:

TABLE 3

Mean Score of Literacy Rate during the year 2009 to 2013:

\begin{tabular}{|c|c|c|c|c|c|}
\hline Years & 2009 & 2010 & 2011 & 2012 & 2013 \\
\hline Average Investment in Cottage Industries (Tk. in lac.) & 20 & 22 & 24 & 25 & 30 \\
\hline Mean Score of Literacy Rate & $40 \%$ & $43 \%$ & $52 \%$ & $54 \%$ & $57 \%$ \\
\hline
\end{tabular}

Sources: Own Field Survey, September 2013 
From the above table we can conclude that when the investment is increasing day by day, literacy rate is also increasing day by day. During the year 2009 investment in cottage industries in our selected sample was 20 lacs and at that period literacy rate was $40 \%$ (both male and female) but when it increased from 20 lacs to 22 lacs, literacy rate also increased from $40 \%$ to $43 \%$. Again when the investment in cottage industries in 2012 was 25 lacs, literacy rate was $54 \%$ but when it increased by 5 lacs, literacy rate increased by $3 \%$. When investment is increasing, earning of the people is increasing, and they can spend more money for their children education. As a result literacy rate is increasing.

(ii) Decrease of poverty rates: Poverty is scarcity, dearth, or the state of one who lacks a certain amount of material possession or money. Absolute poverty or destitution refers to the deprivation of basic human needs, which commonly includes food, water, sanitation, clothing, shelter, health care and education. Relative poverty is defined contextually as economic inequality in the location or society in which people live. (http://en.wikipedia.org/wiki/Poverty). To decrease the poverty rate in Khulna city cottage industries is playing a vital role. To focus this role we have shown our collected data regarding our sample in the following table:

TABLE 4

Contribution to decrease poverty rate during the year 2013:

\begin{tabular}{|c|c|c|c|c|c|}
\hline \multirow[t]{2}{*}{ Factors } & \multicolumn{5}{|c|}{ Mean Score } \\
\hline & $\begin{array}{c}\text { Boutique } \\
\text { shop }\end{array}$ & Nursery & Pottery & Cane & Food \\
\hline Gender equality and empowering women & 1.80 & 1.17 & 1.28 & 0.50 & 0.20 \\
\hline Decreasing unemployment problem & 1.56 & 1.10 & 1.50 & 0.62 & 0.22 \\
\hline Eliminating corruption & 1.50 & 1.43 & 1.30 & 0.76 & 0.18 \\
\hline Increasing income tax & 1.36 & 1.27 & 1.10 & 0.55 & 0.23 \\
\hline Ensuring employment oriented technical education & 1.43 & 1.12 & 0.80 & 0.95 & 0.18 \\
\hline Increasing local govt. participation & 1.68 & 1.08 & 1.31 & 0.21 & 0.11 \\
\hline Reducing poverty & 1.58 & 1.25 & 1.36 & 0.85 & 0.23 \\
\hline Enhancing economic solvency & 1.85 & 1.46 & 1.15 & 0.56 & 0.30 \\
\hline
\end{tabular}

Source: Own Field Survey, (September November ) 2013

From the above table it can be said that out of the five samples, boutique shop is contributing more to decrease poverty rate during the year 2013. Cane and food sectors are contributing less to decrease poverty rate. On the other hand Nursery sector remains at the second position out of the five sectors. Pottery sector is also contributing more to decrease poverty rate but it is not like boutique shop and nursery sectors.

(iii) Maintain price stability: Price stability refers to the general level of prices in the economy avoiding both inflation and deflation. Under price stability people can recognize changes in relative prices. Cottage industries are maintaining the price stability of their goods. As a result people are running their industry with their same purchasing power. To focus this we have arranged our collected data into the following figure based on the average price of each sector.

Figure 01: Average price charged by five sectors during the year 2012 and 2013

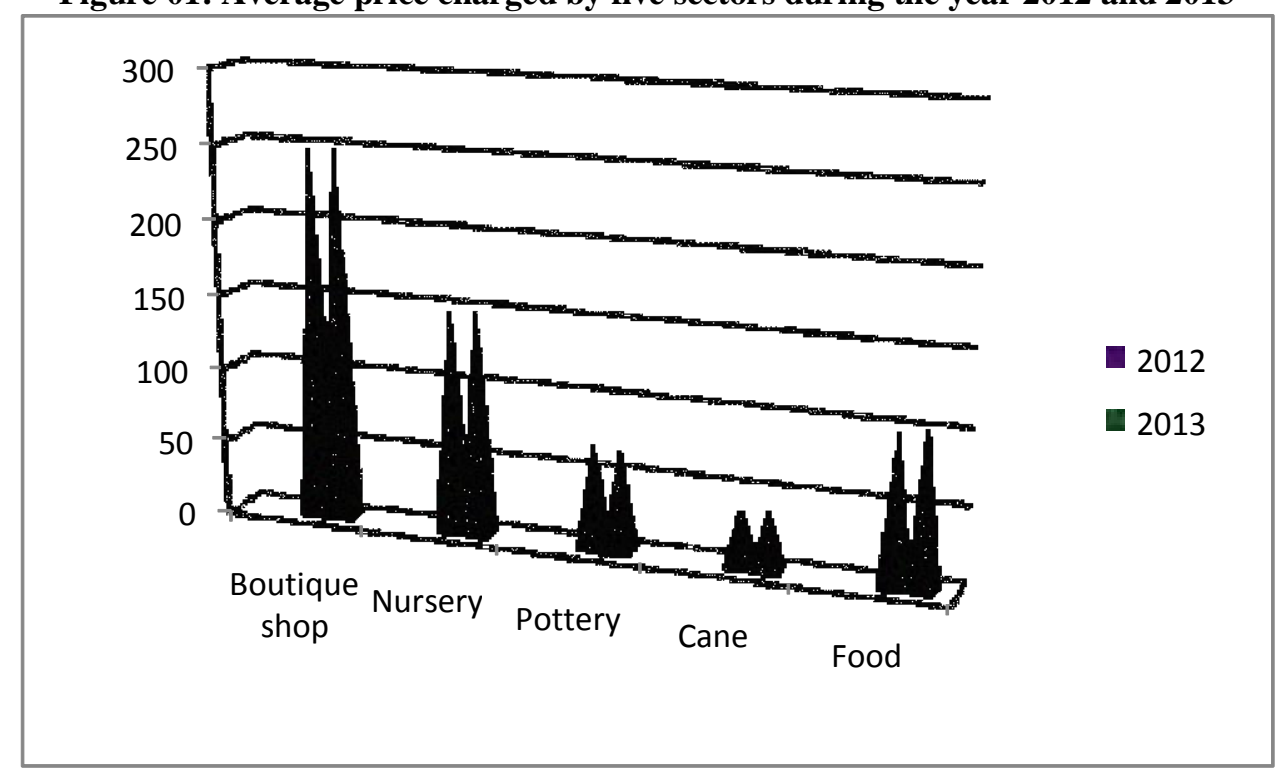

Source: Own Field Survey, (September - November ) 2013 
From the above figure it is observed that each sector maintains its price stability. During the year 2012 the average price charged by boutique shop was Tk.250 where during the year 2013 the average price was Tk.255 that is near to Tk250. During the year 2012 the average price charged by nursery was Tk. 150 where during the year 2013 the average price was Tk.152 that is near to Tk150. During the year 2012 the average price charged by pottery was Tk.70 where during the year 2013 the average price was Tk.70 that is same. During the year 2012 the average price charged by cane was Tk. 40 where during the year 2013 the average price Tk.40 which is same. During the year 2012 the average price charged by food was Tk.100 where during the year 2013 the average price was Tk.105 that is near to Tk.100.

Income, Expenditure and Profit data of five sectors of Cottage Industry during the year 2012:

TABLE 5

Descriptive Statistics:

\begin{tabular}{|l|c|c|c|c|c|}
\hline Particulars & $\mathbf{N}$ & $\begin{array}{c}\text { Minimum } \\
\text { (TK.) }\end{array}$ & $\begin{array}{c}\text { Maximum } \\
\text { (TK.) }\end{array}$ & $\begin{array}{c}\text { Mean } \\
\text { (TK.) }\end{array}$ & $\begin{array}{c}\text { Standard Deviation } \\
\text { (TK.) }\end{array}$ \\
\hline Income & 5 & 5710 & 72565 & 34508.20 & 27562.99487 \\
\hline Expenditure & 5 & 4400 & 58410 & 27761.80 & 23735.44000 \\
\hline Profit & 5 & 1310 & 14155 & 6692.8000 & 4692.61949 \\
\hline
\end{tabular}

Source: Own Field Survey, (September - November ) 2013

After analysing the data of five sectors the minimum and the maximum amount of income, expenditure and profit have emerged. The above table shows the mean value of income is around Tk.34000 and the expenditure is approximately Tk.28,000 where the profit standard deviation is 4692 . This amount shows how much income is scattered from expenditure.

There are meagre resources to develop large-scale industries. However, a program for developing and promoting small-scale industries both in rural and urban areas is more feasible.

Figure 02: Shows the advantages of establishing small scale industries

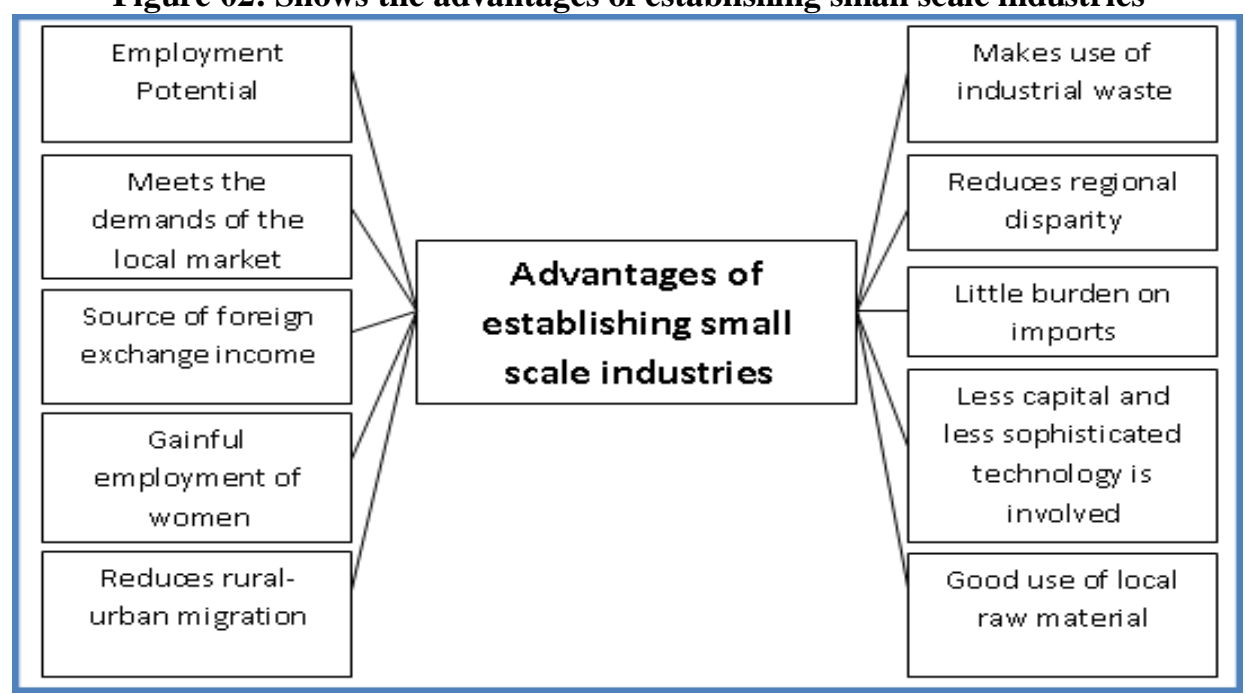

Source: http://en.wikipedia.org/wiki/Cottage_and_small_scale_industries_in_Pakistan, viewed on $16^{\text {th }}$ May, 2014

(i) Cottage and small-scale industries are labor intensive and provide employment to $80 \%$ of the industrial labor force. This reduces the unemployment and offers opportunities for self-employment.

(ii) Traditionally, women are not encouraged to work outside their homes. Cottage or small-scale industries like carpet-weaving, candle-making and handicrafts can be established in houses and women can be gainfully employed. This increases the active labor force.

(iii) These industries also meet the local demands for industrial goods, and save foreign exchange spent in imports.

(iv) There is a demand for rugs, carpets, brassware, handicrafts and embroidered work in the International market. These goods provide $30 \%$ of the export receipts of the manufacturing sector.

(v) When people are employed gainfully in villages, the migration of people from rural to urban areas will reduce. The acute problems of housing, sanitation, education, transport and health will be reduced in urban areas.

(vi) Many districts are under-developed. With the expansion of such industries, the regional disparity in income can be reduced. 
(vii) These industries make effective use of local raw materials which also promote primary industries like agriculture and mining.

(viii) Small-scale industry does not require much capital and high technology. I.T is suited to the traditional economic set-up.

(ix) Cottage and small-scale industries do not use much imported material or equipment.

(x) The waste of large-scale industries, particularly the cotton, sugar and steel industries, can be used to make by-products.

(http://en.wikipedia.org/wiki/Cottage_and_small_scale_industries_in_Pakistan, viewed on 16 ${ }^{\text {th }}$ May, 2014

\section{Formulation and Testing Hypothesis:}

Now focus is on formulating and testing hypothesis related to the role of cottage industry in the economic development. We formulate the hypothesis about the effect of cottage industry in the economic development of Bangladesh.

\section{Hypothesis:}

Ho: Cottage Industry is not playing a vital role in the economic development of Bangladesh.

At the time of study, a questionnaire including some factors related to the economic development was prepared. The respondents expressed their opinions which are given below with expected frequencies. Here the number of people who provided negative answers is also mentioned in the table.

TABLE 6

\section{Observed and Expected frequencies}

\begin{tabular}{|c|c|c|}
\hline Factors & $\begin{array}{c}\text { Observed } \\
\text { Frequencies }\end{array}$ & $\begin{array}{c}\text { Expected } \\
\text { Frequencies }\end{array}$ \\
\hline To improvements of literacy rates & 10 & 50 \\
\hline To decrease of poverty rates & 08 & 50 \\
\hline To maintain price stability & 07 & 50 \\
\hline To provide infrastructure & 08 & 50 \\
\hline For high employment & 05 & 50 \\
\hline For workforce training and real estate development & 06 & 50 \\
\hline
\end{tabular}

\section{Sources: Own Field Survey, (September - November ) 2013}

For hypothesis testing we have used Chi-Square static. We know,

$$
x^{2}=\sum \frac{(O-E)^{2}}{E}
$$

Where,

$$
\begin{aligned}
& x^{2}=\text { Chi-square statistic } \\
& \mathrm{O}=\text { Observed Frequency } \\
& \mathrm{E}=\text { Expected Frequency. }
\end{aligned}
$$

Calculation of $x^{2}$

\begin{tabular}{|c|c|c|c|c|}
\hline $\begin{array}{l}\text { Observed Frequencies } \\
(O)\end{array}$ & Expected Frequencies $(E)$ & $(O-E)$ & $(O-E)^{2}$ & $\frac{(O-E)^{2}}{E}$ \\
\hline 10 & 50 & -40 & 1600 & 32 \\
\hline 08 & 50 & -42 & 1764 & 35.28 \\
\hline 07 & 50 & -43 & 1849 & 36.98 \\
\hline 08 & 50 & -42 & 1764 & 35.28 \\
\hline 05 & 50 & -45 & 2025 & 40.50 \\
\hline 06 & 50 & -44 & 1936 & 38.72 \\
\hline \multicolumn{5}{|r|}{} \\
\end{tabular}

Here,

$x^{2}=218.76$

Degree of freedom $(\mathrm{df})=\mathrm{k}-1,=6-1=5$

Where $\mathrm{k}=$ number of cells associated with row or column data 
The critical /table value of $x^{2}$ for 5 degree of freedom is at 0.05 level of significance is 12.60 . Here the calculated value of $x^{2}$ is greater than the table value so the null hypothesis is rejected and we can conclude that Cottage Industry is playing vital role in the economic development of Bangladesh.

\section{Problem Associated With The Cottage Industry}

Problem associated with the cottage Industry are given below:

1. The first problem is the collection of raw materials mainly the raw cane due to the much dependent on the cane of the outside country.

2. As modern machinery is not used in the cane industry, labourers cannot produce such quickly as they can produce a single product at a time. So it is a time consuming production process and thus requires more labour wage. As a result the price of cane products become higher and the demand of the consumer decline.

3. Production of food is a risky business. It becomes more risky when food producers are unskilled, uneducated and having low knowledge about the information of commodities

4. The wage of the workers who are engaged in nursery business is very negligible.

5. There is some child labor in the nursery.

6. For natural calamity the products of the nursery is destroyed.

\section{Prospect Of Cottage Industry}

Prospects of Cottage industry are shown below:

1. If there is better transport and communication all over Bangladesh especially in the rural areas the cottage industry can contribute a lot to the integrated rural development.

2. It also provides the women workers with opportunities to participate in economic activities.

3. It reduces poverty to some extent and as a result enhances the way of economic solvency to the same extent.

4. If an extensive help from the Government (GO) and Non-government Organizations (NGO) is obtained in the creating of export facilities, then it will be a profitable sector that contributes to our GDP.

5. Establishment of industrial estates.

6. Providing marketing facilities.

7. Setting up of technical service centers.

8. Establishing handicraft development centers and carpet centers.

9. Providing per-investment counseling and guidance to newcomers.

10. Providing local and foreign loans to small industry owners on easy instalments.

\section{Findings}

1. All the nurseries are operated sole ownership business.

2. There is lack of capital in these sectors.

3. The people who are working in the show-rooms are also educated and most of them are female.

4. In our survey, we find that most of the people who are involved with the boutique business are women, so, by the boutique business, some empowerment for women may have ensured a little bit as they operate some earnings.

5. In our study, we find some of the boutique shops who have insurance for their shop.

6. Some of owners reinvest their profit in the boutique shop and some other does not make re-investment rather than operate their daily expenses and some make both reinvestment and operating of expenses.

7. Boutique shop is contributing more to decrease poverty.

8. Lack of entrepreneurial ability among the entrepreneurs of these industries.

9. Shortage of manpower in a cottage industry engaged in either manufacturing or servicing, generally run either full-time or part-time by family members and as Small-scale establishments includes those with fewer than 10 workers.

10. It cannot achieve economies of scale as it is run as a small scale basis.

11. The potters of this area are producing only limited products and again the demand for some products varies with several factors. This is also limiting their production. Such as during the festivals they are producing toys and other fancy products. During summer the pitchers have great demand and during the winter the caves of cakes have large demand that their products have no year round demand

12. With the introduction of substitute goods, the demand for pottery products drastically reduced. As a result, its production gradually decreases.

13. Most of the labourers are unskilled, some of them are semiskilled and a very few of them are skilled. So there is inefficiency in the production of goods as still today most of the people working or related to this kind of profession do not get training facilities either from GOs or from NGOs in Bangladesh

14. Cottage industry is giving opportunity to the women to participate in an economic activity 


\section{Ecommendations}

1. Transport and communications should be developed.

2. Extensive training is necessary for the deprived area of the country.

3. Necessary support to the entrepreneurs should be given by both GOs and NGOs especially in the deprived areas.

4. Small and Cottage industries producing handicrafts for International Trade Fairs should be given proper support by the govt.

5. Cooperation and coordination among a specific artisan group is required.

6. Disguised labourers in the agriculture sector should be shifted to the Small and Cottage industries.

7. To remove the scarcity of credit, adequate credit facilities should be provided. For this purpose, a special credit department, BSCIC, should be active immediately in the city. Moreover, the terms and conditions should be easy for the entrepreneurs.

8. Modernization is needed to produce better qualitative products so that the demand for the products may increase. For this, modern machinery should be used for better finishing of the products.

9. Division and categorization of the products should be introduced according to the quality.

10. For the development of the cottage industry, research is needed. The research should be on the basis of consumer's choice, taste, quality of produced products, how to improve the quality, present condition, how to enter into the foreign market and how to capture the domestic market etc.

11. Easy loan may be supplied to the entrepreneur.

12. The wage level of the labors must be increased.

13. It is necessary to take proper steps to protect the products from natural disaster.

14. Effective sales persons are needed for promoting the sales rate.

\section{Conclusion}

Now it is obvious that the present status of cottage industry in Khulna City as well as in the whole country is not so good. At the same time it is clear that it has a great role in our economy. So it is very necessary to improve the present condition of cottage industry. If the market for cottage products is expanded, this will improve our own culture. Cottage industries provide economic opportunities to the poor or the middle-income section of people through employment in Bangladesh. Cottage industries have already achieved its own tradition, but it was mainly rural-based. On account of modern technological development, this sector finds its spreading in urban areas and is making more attractive and highly finished exportable products. Now-a-days due to pressure of large industry and less government intervention as well as various problems associated with credit programme etc. impede the dynamic growth of small and cottage industries. The contribution of this sector is satisfactory as there is huge opportunity of employment generation, it helps the people to be self employed, and it fulfils not only our local demand but also the demand outside the country.

\section{References}

[1]. Asian Development Bank (ADB), Bangladesh 2002 Strategic Issues and Potential Response-Small and Medium Enterprise Development and Export Expansion, Dhaka, Bangladesh Economic Review 2012

[2]. BAUEC. 2001. Annual Report 1999-2001.Bangladesh Agricultural University Extension Center, BAU, Mymensingh.

[3]. Bangladesh Small \& Cottage Industries Corporation (BCSIS), 1994, Survey on Cottage industry.

[4]. GRAZIANO DA SILVA, J.; 1998 Projeto Rurbano, Fundação de Apoio à Pesquisa de São

[5]. http://dictionary.reference.com/browse/boutique, viewed on $13^{\text {th }}$ May, 2014

[6]. http://dictionary.reference.com/browse/cane, viewed on $13^{\text {th }}$ May, 2014

[7]. http://dictionary.reference.com/browse/food, viewed on $13^{\text {th }}$ May, 2014

[8]. http://en.wikipedia.org/wiki/Boutique, viewed on $13^{\text {th }}$ May, 2014

[9]. http://en.wikipedia.org/wiki/Cottage_and_small_scale_industries_in_Pakistan, viewed on $16^{\text {th }}$ May, 2014

[10]. http://en.wikipedia.org/wiki/Methodology, viewed on $14^{\text {th }}$ May, 2014

[11]. http://en.wikipedia.org/wiki/Plant_nursery, viewed on $13^{\text {th }}$ May, 2014

[12]. http://en.wikipedia.org/wiki/Pottery, viewed on $13^{\text {th }}$ May, 2014

[13]. http://www.banglapedia.org/HT/C_0423.htm, viewed on $13^{\text {th }}$ May, 2014).

[14]. http://www.bpedia.org/C_0356.php, viewed on $13^{\text {th }}$ May, 2014).

[15]. http://www.svbic.com/node/24, viewed on $16^{\text {th }}$ December, 2013

[16]. Khandoker, S.R., 1998. "Fighting Poverty with Microfinance: Experience with Bangladesh" (Dhaka, UPI)

[17]. Khurshida, Begum, 1992. Involvement of women in economic and social development. (Dhaka, Bangladesh Employers' Association).

[18]. MARX, K. O 1987 Capital. São Paulo, Editora Bertrand Brasil, Seed working paper No. 14 (PDF), Series on Women's Entrepreneurship Development and Gender in Enterprises - WEDG; Jobs,

[19]. The New Nation, 2010 Editorial Page, Policy support for small and cottage industries.

[20]. The News Today, 2012 BUSINESS; Dhaka; Small and Cottage fair begins in city.

[21]. www.bdobserver.com, viewed on $25^{\text {th }}$ December, 2013 